\title{
Impact of Irrigation Water Price and Technological Progress on Agricultural Water Intensity in Amrawati Area, Maharashtra
}

\author{
Dr. Shalini M. Guldeokar \\ S. P. College, Department of Geography, Post Graduate and Research Center, Pune-30, India \\ guldeokarshalini@yahoo.com
}

\begin{abstract}
India is an agricultural country nearly sixty five percent population is engaged in agricultural activity. To fulfill the demand of population of country are growing Crops in combination because some region is not suitable for all crops so they grow in Crop combinations. Crop combination, agricultural intensity and irrigation intensity, crop concentration and crop diversification is an important indicators of common cropping pattern in any geographical unit and hence the key determinant of the agricultural economy. Total altogether thirty three crops have been considered for crop combination, agricultural intensity analysis, among these nine crops are major crops wheat, Jowar, Bajara, yellow gram, Tur, Green gram, Black gram, cotton and Orange etc. In the present study discusses about the crop combination, agricultural intensity and irrigation intensity because this region lies in moderate rainfall zone most of the agriculture is based on rainfall so has tried to identify the irrigation intensity.
\end{abstract}

Keywords: Agriculture, Crop Combination, Determinant, Intensity, Rainfall

\section{Introduction}

Agricultural intensity means net sown areas are used to growing crops more than once in one agriculture year. It indicates the numbers of crops produced in a field during one agriculture year. The agricultural intensity depends on the geo-climatic, pedagogical, socio-cultural, and infrastructural factors. Thus, the agricultural intensity is generally high in the well irrigated area Contrary to this; the agricultural intensity is low in the less rainfall recording areas. Hence irrigation is important to grow crops, there are many sources of water supply are available like surface, ground water etc., which are being used for irrigation and other purposes. But those sources are not available uniformly. The irrigation intensity is an indicator of the level of irrigational facilities in respect of the arable land (Pandey, 1992, p.99). It reflects the level of agricultural development with regard to irrigational facilities.

\section{Study Area}

Amravati district is situated right in the center of the northern border of Maharashtra. It lies between $20^{\circ} 32^{\prime}$ north to $21^{\circ} 46^{\prime}$ north latitudes and $76^{\circ} 37^{\prime}$ east to $78^{\circ} 27^{\prime}$ east longitudes. It is bounded in north by state of Madhya Pradesh, in the east by Nagpur and Wardha districts, and in the south and south-west by Yavatmal, Akola and Buldhana districts. According to census 2011 total population of district was $28,87,826$ and population density is 237 per person, Amravati District is located in the Deccan plateau, district has covers an area of 12626 sq.kms.

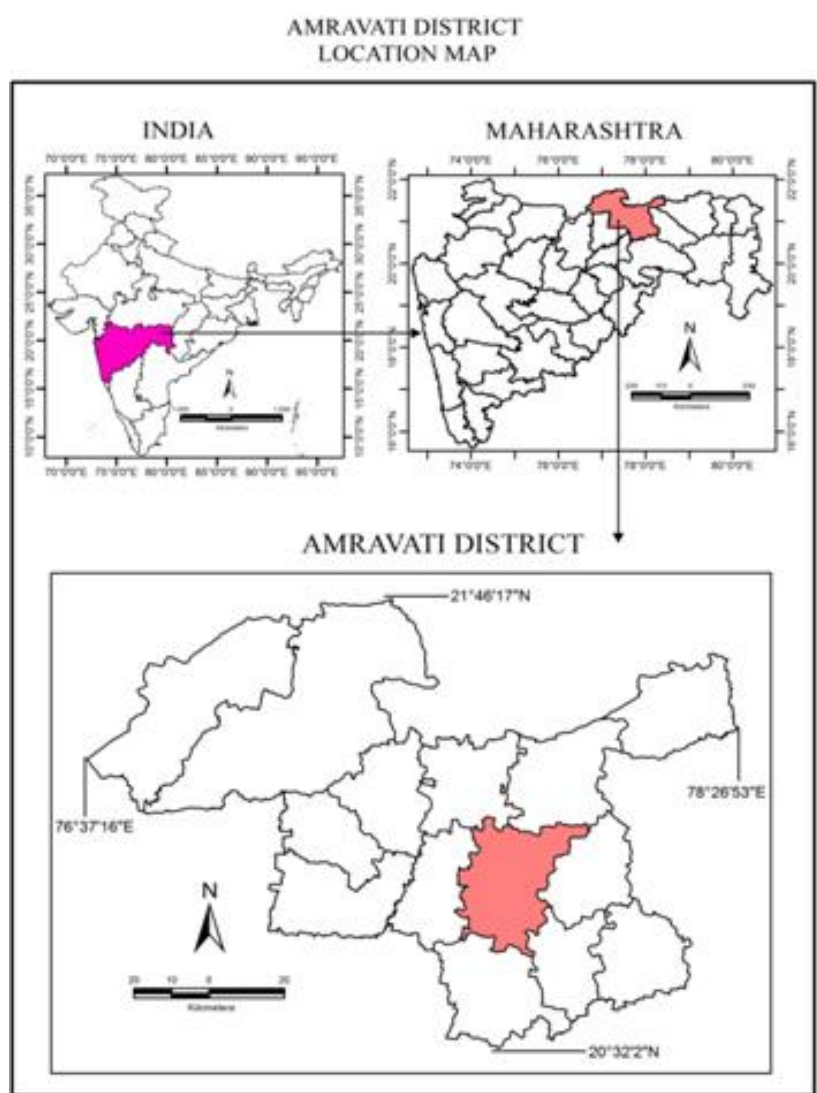

Objectives of the Study:

The main objectives of the present study are outlined.

1) To study existing cropping pattern of the study area.

2) To analyze the spatial pattern of crop combination.

3) To study the agricultural and Irrigation Intensity.

\section{Methodology}

The present study is based on secondary data. The secondary data has been collected from government and non-government sources, data have been collected from 
Agricultural Department and Socio-economic statistical abstract of Amravati District (2015), Population data was collected from Census of Amravati.

To calculate crop combination, Rafiullha's method has used and for agriculture and irrigation intensity GIS techniques has used.

\section{Land use Pattern of Amravati District}

Land is the most vital resources of a country, it is fixed asset and cannot be expanded to meet the needs of an increasing population. Therefore it must be used carefully and in the best possible manner. Land is available in the form of plains, plateaus, hills and mountain. In Amravati district also some land devoted to agriculture some land under forest. Table no. 1 shows land use pattern in Amravati district

Table 1: Land use Pattern of Amravati District Area in Hectares

\begin{tabular}{|c|c|c|c|c|c|c|c|}
\hline & Total Geographical Area & Forest & Land not available for cultivation & Uncultivable & Fallow land & Total cropped area & Cultivated land \\
\hline District & 1167911 & 320562 & 40675 & 50002 & 91048 & 711923 & 743236 \\
\hline
\end{tabular}
(Source: Cropping Report 2007-08)

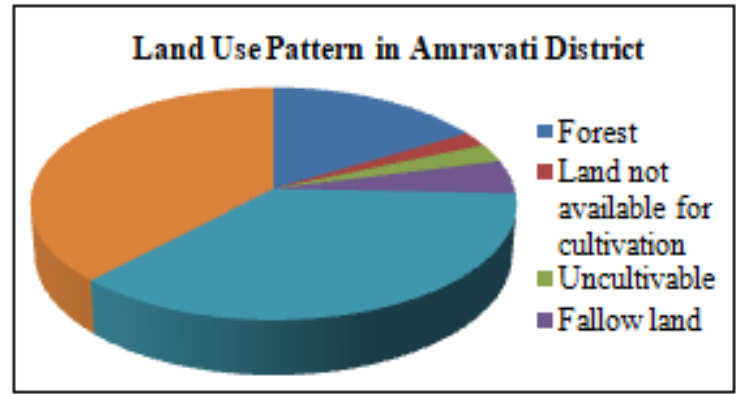

Figure 1

\section{Suitable condition}

Suitable temperature and rainfall are essential for plant growth; most plants need a minimum temperature and rainfall similarly sufficient amount of sunshine also necessary for plant growth. Rainfall is a significant factor in agriculture, excess or deficiency in rainfall casus severe crop losses.
Table 2: Tahsilwise Rainfall (2015)

\begin{tabular}{|c|c|}
\hline Name of Tahsil's & Annual Rainfall mm \\
\hline Dharani & 100.63 \\
\hline Chikhaldara & 81.28 \\
\hline Anjangaon Surji & 149.46 \\
\hline Achalpur & 142.32 \\
\hline Chandur Bazar & 119.13 \\
\hline Morshi & 111.50 \\
\hline Warud & 108.86 \\
\hline Tiosa & 110.83 \\
\hline Amravati & 138.08 \\
\hline Bhatkuli & 143.86 \\
\hline Daryapur & 144.35 \\
\hline NandgaonKhandeshwar & 118.24 \\
\hline Chandur Railway & 104.27 \\
\hline Dhamangaon Railway & 124.17 \\
\hline
\end{tabular}

(Source: District agriculture Department)

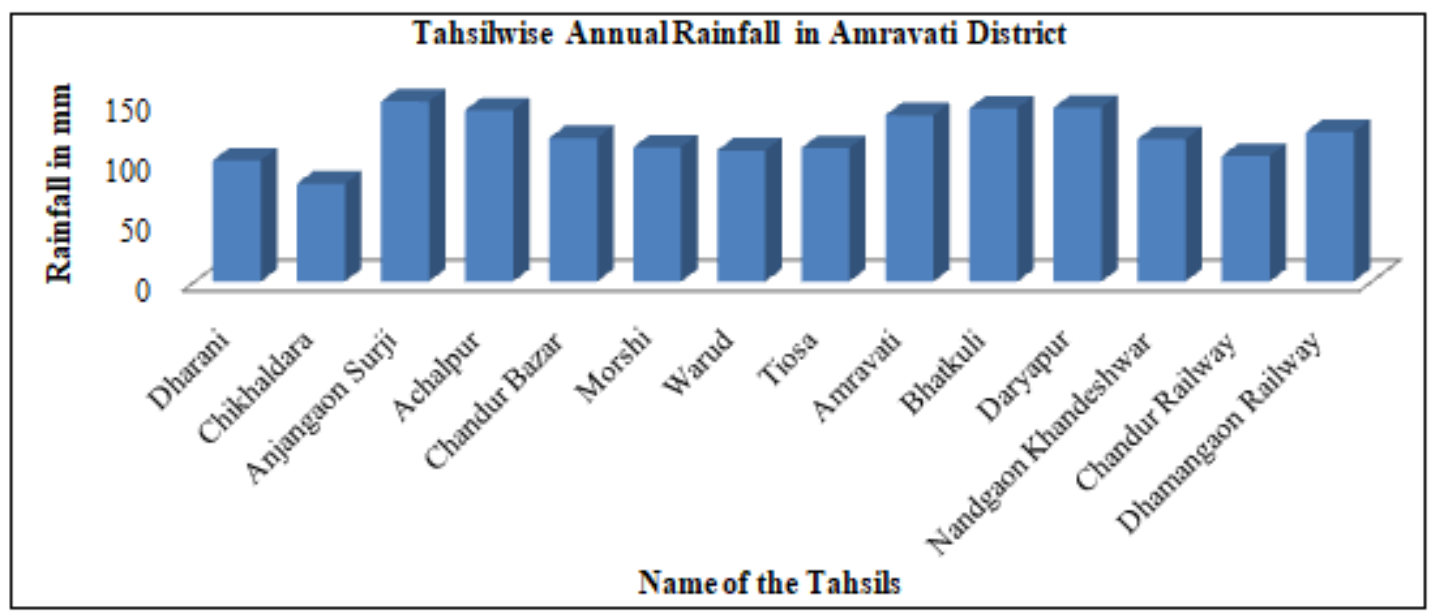

Figure 2

\section{Result and Discussion}

The results and discussion related to the changes in the pattern of Crop Combination, agricultural Intensity and Irrigation Intensity in Amravati district, is determined by the topography and climate including temperature, rainfall, availably of water.

\section{Cropping Pattern in Amravati District:}

According to Socio-economic abstract of 2015 of Amravati district it observed that thirty three crops are grow in district but the percentage is very less among these crops as food grains wheat, jowar, bajara and rice crops has selected, as pulses gram, tur, green gram and black gram has selected and as a cash crops cotton, orange and chilly has selected because these crops has occupied more area. 
Table 3: Tahsilwise Area under Cultivation of Different Crops in Amravati District

\begin{tabular}{|c|c|c|c|c|c|c|c|c|c|c|c|c|}
\hline Sr. No. & Tahsil's & Wheat & Jowar & Bajara & Rice & $\begin{array}{c}\text { Yellow } \\
\text { Gram }\end{array}$ & Tur & $\begin{array}{c}\text { Green } \\
\text { gram }\end{array}$ & $\begin{array}{l}\text { Black } \\
\text { Gram }\end{array}$ & Chilly & Orange & Cotton \\
\hline 1 & Dharani & 0.62 & 0 & 1.35 & 98.23 & 3.62 & 0.64 & 0.35 & 0 & 0 & 0 & 1.1 \\
\hline 2 & Chikhaldara & 4.86 & 5.34 & 8.4 & 0 & 0.72 & 1.62 & 3.3 & 18.5 & 0.22 & 0 & 0.24 \\
\hline 3 & Anjangaon Surgi & 6.45 & 6.88 & 0 & 0 & 1.1 & 3.40 & 2.7 & 0 & 1.1 & 0.8 & 9.6 \\
\hline 4 & Achalpur & 17.28 & 14.89 & 5.1 & 0 & 0.45 & 33.91 & 1.48 & 2.24 & 12.6 & 11.8 & 10.3 \\
\hline 5 & Chandurbazar & 10.32 & 0.95 & 5.5 & 0 & 5.49 & 5.29 & 1.02 & 27.5 & 9.6 & 7.7 & 3.4 \\
\hline 6 & Mori & 8.02 & 4.89 & 3.2 & 0 & 6.14 & 7.40 & 1.7 & 7.58 & 5.7 & 16.1 & 8.1 \\
\hline 7 & Warud & 6.36 & 10.69 & 14.2 & 0.78 & 1.52 & 4.10 & 0.17 & 0.9 & 27.5 & 36.9 & 3.2 \\
\hline 8 & Tiosa & 10.69 & 5.30 & 0 & 0 & 6.81 & 4.71 & 0.42 & 0.24 & 0.6 & 6.7 & 6.4 \\
\hline 9 & Amravati & 4.78 & 11.10 & 11.1 & 0 & 6.16 & 4.79 & 7.43 & 32.6 & 1.2 & 5.8 & 10.7 \\
\hline 10 & Bhatkuli & 0 & 0 & 0 & 0 & 31.95 & 8.69 & 33.51 & 7.45 & 0 & 0.42 & 0 \\
\hline 11 & Daryapur & 0 & 10.11 & 0 & 0 & 33.52 & 6.18 & 37.66 & 0 & 0 & 0 & 17.9 \\
\hline 12 & Nandgaon & 7.88 & 13.34 & 11.3 & 0.26 & 0.06 & 0 & 0 & 0 & 2.2 & 4.8 & 18.1 \\
\hline 13 & Chandur Railway & 22.71 & 17.3 & 39.6 & 0.27 & 2.6 & 19.5 & 10.1 & 2.5 & 35.4 & 8.7 & 10.9 \\
\hline
\end{tabular}

(Source: Cropping Report 2015)

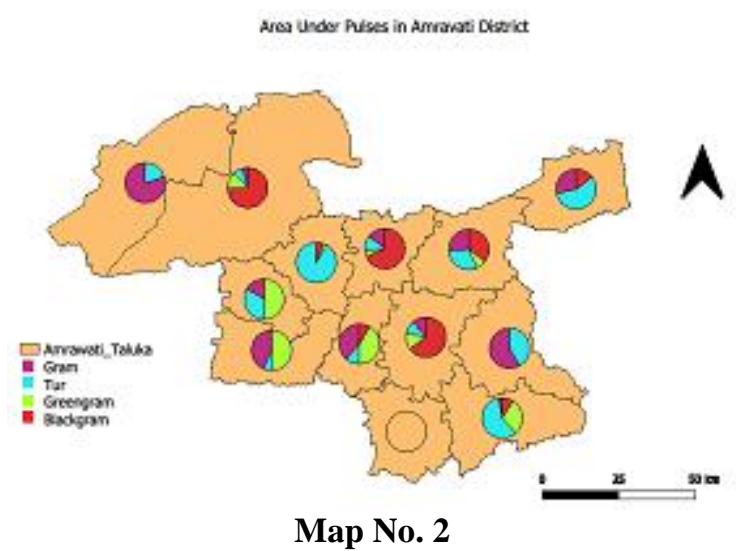

Map No. 2
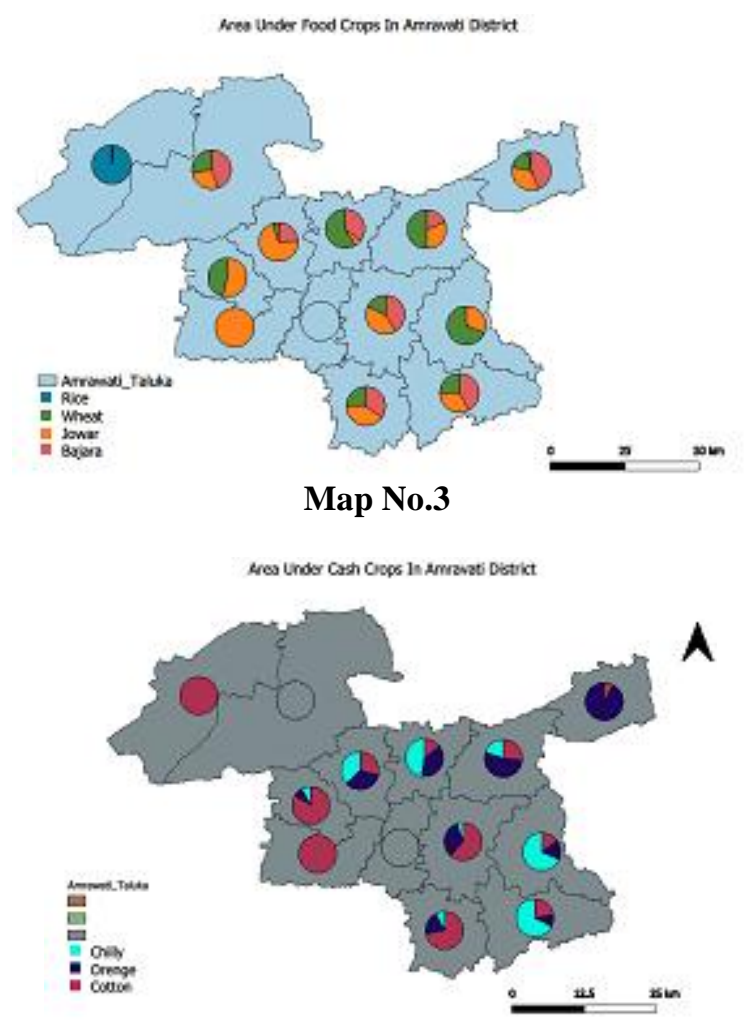

Map No. 4

Above maps shows the area under different crops, it observed that in Nandagaon Khandeshwar tahsils pulses are not cultivated due to climatic condition. It has noted that in Bhatkuli tahsils food crops are not cultivating and it observed that in Chikhaldara tahsil's due to topography cash crops not cultivated.

\section{Crop Combination}

The crop combination analysis is required for establishment of relationship in various cultural characteristics. It provides good idea for agricultural regionalization. This technique has the capacity to handle the highly diversified cropping structures. The crop combinations demarcated on the basis of statistical techniques provide a sound base for agricultural planning and development.

Raffiullah's statistical techniques is more accurate and rational, therefore it is quite popular for delineation of crop combination region hence maximum positive deviation method of Raffiullah's has used to analyze the data with the help of following formula.

$$
\mathrm{d}=\sqrt{\frac{\Sigma \mathrm{D}_{\mathrm{p}}^{2}-\mathrm{D}_{\mathrm{n}}^{2}}{\mathrm{~N}^{2}}}
$$

$\mathrm{D}=$ deviation

Dp $=$ Positive difference

Dn = Negative difference from the medial value of the theoretical curve value of the combination

$\mathrm{N}=$ Number of crops

Table 4: Tahsilwise Crop Combination in Amravati District (2015)

\begin{tabular}{|c|c|c|c|c|}
\hline $\begin{array}{c}\text { Sr. } \\
\text { No. }\end{array}$ & $\begin{array}{c}\text { Name of } \\
\text { Tehsil }\end{array}$ & $\begin{array}{c}\text { Index value } \\
\text { of Crop } \\
\text { Combination }\end{array}$ & Category & $\begin{array}{c}\text { Crops in } \\
\text { combination }\end{array}$ \\
\hline 1 & Dharani & 2452.76 & $\begin{array}{c}\text { Two crop } \\
\text { combination }\end{array}$ & $\begin{array}{c}\text { Rice and } \\
\text { Yellow Gram }\end{array}$ \\
\hline 2 & Chikhaldara & 992.25 & Monoculture & Black Gram \\
\hline 3 & $\begin{array}{c}\text { Anjangaon } \\
\text { Surgi }\end{array}$ & 1632.16 & Monoculture & Cotton \\
\hline 4 & Achalpur & 258.88 & Monoculture & Tur \\
\hline 5 & Chandurbazar & 1149.21 & Monoculture & Orange \\
\hline 6 & Mori & 171.61 & Monoculture & Orange \\
\hline 7 & Warud & 1545 & Monoculture & Wheat \\
\hline 8 & Tiosa & 302.76 & Monoculture & Black gram \\
\hline 9 & Amravati & 152.27 & Monoculture & Green Gram \\
\hline 10 & Bhatukli & 271.32 & Monoculture & Green gram \\
\hline 11 & Daryapur & 1017.61 & Monoculture & Cotton \\
\hline 12 & Nandgaon & 295.84 & Monoculture & Chilly \\
\hline 13 & Chandur & 408.04 & Monoculture & Bajara \\
\hline
\end{tabular}


Above table no. 4 shows crop combination of tahsils, it observed except Dharani tahsils shows two crops combination with Rice and Yellow Gram the variance of Rice is 2452 due to high rainfall.

Remaining all thasils have monoculture crops due to less rainfall some crops required less rainfall so these tahsils shows monoculture, like Black gram, Cotton, Tur, Orange, Orange, Wheat, Black Gram, Green Gram, Chilly and Bajara.

\section{Agricultural Intensity:}

Agricultural intensity means net sown areas are used to growing crops more than once in one agriculture year. It indicates the numbers of crops produced in a field during one agriculture year. It refers to how various inputs are important like land, labor, seeds, fertilizers and chemicals ect to enhance the yield and profitability in a given year. On the other hand the crop intensity refers to numbers of crops raised in a unit area in a given year. To calculate agricultural intensity following formula has used.

$$
\mathrm{ICi}=\frac{\text { Gross Cropped area }}{\text { Net sown area }} \times 100
$$

where,

$\mathrm{ICi}=$ Cropping Intensity Index

Gross Cropped area $=$ Net acre sown + Area sown more than once

If we observed the following map, it noted that in Dharani tahsil agricultural intensity is high it means they are growing crops more than once in one year and in Batkuli tahsil's intensity is very low.

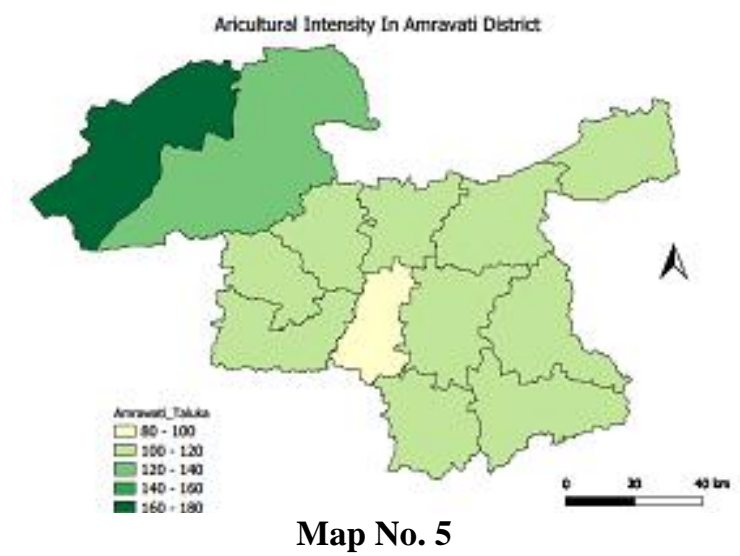

\section{Irrigation Intensity}

Irrigation is an primeval approach to promoting agricultural development but irrigation is important for agricultural production, because in the present day modernized agricultural pattern, the increasing use of modern agricultural inputs and use of various chemicals for soil conservation more effective, require more water for irrigation. If less use of agricultural inputs results is that low level of production.

Hence Irrigation is essentially the artificial application of water to overcome deficiencies in rainfall for growing crops. Irrigation as a protective measure to supplement rainfall and precaution against the failure of crops is always practices in various parts of the world. Irrigation is very vital to overcome the basis problems of the agriculture. Irregular, uncertain and unevenly distribution of rainfall in time amount and space is not sufficient for growing certain crops. These conditions make irrigation is essential for the successful crop production. The intensity of irrigation means the percentage ratio between the net areas irrigated to net area sown. To identify irrigation intensity following formula has used.

$\mathrm{Ii}=\quad \frac{\mathrm{NIa}}{\mathrm{NAs}} \times 100$

$\mathrm{Ii}=$ Irrigation intensity;

Nla $=$ Net irrigated area

$\mathrm{NAs}=\mathrm{Net}$ sone area

Tarsi wise lmigrton Intonsty in Amavirs District

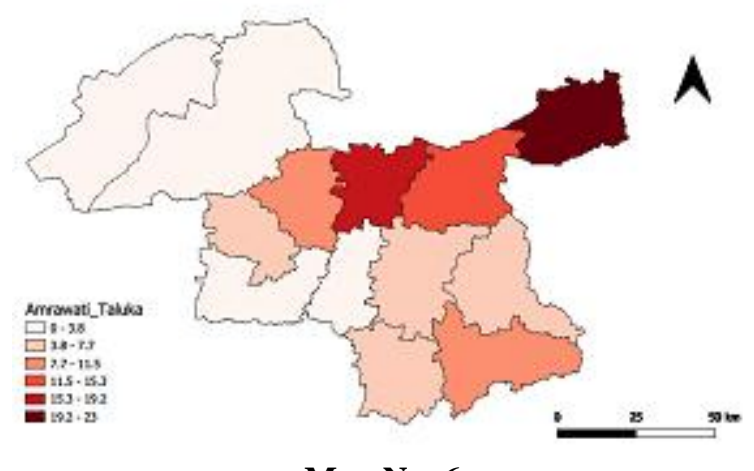

Map No. 6

It observed that Dharani ,Chikhaldara, Bhatkuli and Daryapur tahsil's irrigation intensity is very less because of unavailability of irrigation facilities and Warud and Morshi shows high irrigation intensity due to availability of irrigation facilities because Upper wardha Dam and Shibhora Dam are very closed to these places.

\section{Conclusion}

The crop combination, agricultural intensity and irrigation intensity is direct impact of rainfall. Except Dharani tahsils all thasils shows monoculture crops, in Dharani having two crop combinations with rice and Yellow gram. Black gram and Green gram are mostly grows in Amravati, Tiosa, Bhatkuli and Chikhaldar, Orange grows in Morshi and Chandur bazaar tahsils. Other important crops are Cotton, Chilly, Tur, Bajara grow as a monoculture. Agricultural intensity is high it means they are growing crops more than once in one year and in Batkuli tahsil's intensity is very low. Some tahsils shows high irrigation intensity due to availability of irrigation facilities.

\section{References}

[1] Bhaha S. S. (1965) Economic Geography pp. 40, 41, 53, 55

[2] Bhatia, S.S., (1965). "Patterns of Crop Concentration and Diversification in India", Economic Geography, 41. pp. 40-56.

[3] Jasbir Singh (1976) Agricultural Geography, Tata McGraw Hill Publishing Co. Ltd. New Delhi, p. 221

[4] Majid Husain (1996) Systematic Agricultural Geography, Reprinted 2004, Rawat publication, Jaipur and new Delhi, pp. 217, 218 
[5] Patil Arun (2019) "Patten of Crop Combination in Kolhapur District", Maharashtra Bhugolshastra Sanshodhan Patrika, Pune, Vol. 36 No.2, pp 72-78

[6] Punithavathi J and Baskaran R. (2010) "Changes in the Cropping Pattern, Crop Concentration, Agricultural Efficiency in Papansam Taluk, Thanjavur District, Tamil Nadu, India, Recent Research in Science and Technology, Vol. 2, No. 5, pp 1-7

[7] Sannashiddannanavar S.S. and S Bindumati (2016) "Dynamics of Cropping Pattern in Hemavathi Watershed Karnataka State" The Deccan Geographer, Vol. 54, No. 1, pp87-94

[8] Sharma Y.K. (2010) Agricultural Geography, Lakshmi Narayan Agarwal Publication, Agra

[9] Singh Jasbir (1974) An agricultural Atlas at India, - A Geographical analysis, Kurukshetra, Vishal Publication, 